ISSN: 2224-0616

Int. J . Agril. Res. Innov. \& Tech. 4 (2): 41-45, December, 2014 Available online at http:// www.ijarit.webs.com

\title{
FACTORS AFFECTING THE MILK PRODUCTION OF DAIRY CATTLE IN NORTHERN RURAL AREAS OF BANGLADESH
}

\author{
M.R. Begum", M. Anaruzzaman' ${ }^{2}$, M.S.I. Khan ${ }^{3}$ and M. Yousuf ${ }^{4}$
}

Received 30 June 2014, Revised 6 November 2014, Accepted 22 December 2014, Published online 31 December 2014

\begin{abstract}
A cross sectional study was conducted to observe the factors affecting the productive performance of dairy cattle from northern rural areas of Bangladesh during July and September 2013. Data of 105 cows, 85 (80.95\%) from local and 20 (19.05\%) cows from cross breed, were randomly selected for the study. A binary logistic regression, expressed by odds ratio with $95 \%$ confidence interval, was done to determine the association of daily milk production categorized into $\leq 2$ and $>2$ liters (L), based on median, with the significant explanatory variables of body weight, age at first calving, lactation period, vitamin use, type of floor and milking person. The result demonstrated that the probability of milk production of $>2 \mathrm{~L}$ was $6.16,4.5,20.65$ and 5.7 times higher from the with animal body weight of $>140$ $\mathrm{kg}$, age at first calving of $>36 \mathrm{~m}$, lactation period of $>8 \mathrm{~m}$ and vitamin use than that of body weight of $\leq 140 \mathrm{~kg}$, age at first calving of $\leq 36 \mathrm{~m}$, lactation period of $\leq 8 \mathrm{~m}$, and not vitamin used respectively. The chance of milk production of $>2 \mathrm{~L}$ was 0.25 and 0.22 times lower for mud floor, and owner milking than that of brick floor and gowala (professional milking person) respectively.
\end{abstract}

Keywords: Breed, Factors, Milk Production, Odds Ratio, Logistic Regression

\footnotetext{
${ }^{1}$ Assistant Professor, Department of Agricultural Economics and Social Sciences, Chittagong Veterinary and Animal Sciences University, Khulshi, Chittagong, Bangladesh

${ }^{2}$ Doctor of Veterinary Medicine, Chittagong Veterinary and Animal Sciences University, Khulshi, Chittagong, Bangladesh

${ }^{3}$ Assistant Professor, Department of Food Microbiology, Patuakhali Science and Technology University (PSTU), Dumki, Patuakhali, Bangladesh

${ }^{4}$ Director (Program), SANGRAM (Sangathita Gramunnyan Karmasuchi), Bangladesh

*Corresponding author’s email: rasustat@yahoo.com (M.R. Begum)
}

\section{Introduction}

An important component of national economy, Bangladesh has 47.51 million livestock of which 22.87 million are cattle, plays a vital role for economic development of Bangladesh (BBS, 2008). Better genotype and sound management are the major determinants of profitability of dairying at either farm or individual level (Djemali and Freeman, 1987; Rahman et al., 1987) although, performances of high yielding exotic crossbred cows may differ among different geographical areas (Jahan et al., 1990; Alam and Ghosh, 1994). Biological potential for milk production also depends on the age at puberty, first calving age, number of parity and calving interval (Djemali and Freeman, 1987; Rahman et al., 1987). Around 2 years age of first calving and less than 13 to 14 months calving interval are the indicators of better management index of a farm (Wiltbank, 1970; Sarder, 2001). Besides, some diseases also have influence on the milk production where mastitis is one of the most devastating and farmers in Bangladesh are not well aware of the best practices to control (Rehman et al., 1997). For good health and high milk yields, cows need to be fed the proper amounts of available minerals and vitamins (Weiss, 1998). The present study was therefore undertaken to detect the factors of milk production. To be specific, the goal was to quantify the significant association of milk production with other covariates and factors by implying binary logistic regression model.

\section{Materials and Methods}

A cross sectional study was conducted at Rangpur and Gaibandha districts of northern rural areas of Bangladesh. A total of 105 cows were randomly selected where 85 were local and 20 were cross breed between July and September 2013.

\section{Statistical analysis}

Logistic regression, a type of probabilistic statistical classification model can be used to predict a binary response from a binary predictor and for predicting the outcome of a categorical dependent variable based on one or more predictor variables. 
The simple logistic model has the form

$\operatorname{logit}(y)=\ln \left(\frac{\pi}{1-\pi}\right)=\alpha+\beta_{1} x_{1}$

After simplification,

$$
\pi=\text { Probability }(Y=\text { Outcome of interest } \mid X=x)=\frac{e^{\alpha+\beta_{1} x_{1}}}{1+\theta^{\alpha+\beta_{1} x_{1}}}
$$

Where ' $I n$ ' denotes the natural logarithm, $\pi$ is the probability that the dependent variable of milk production ( $>2$ liters), $\alpha$ is the intercept from the linear regression, $\beta_{1}$ is the regression coefficient multiplied by predictor, $\mathrm{x}$ can be categorical or continuous but $Y$ always categorical. According to equation 1, the relationship between logit $(\mathrm{Y})$ and $\mathrm{X}$ is linear. Yet, according to equation 2 , the relationship between the probability of $\mathrm{Y}$ and $\mathrm{X}$ is nonlinear. For this reason, the natural log transformation of the odds in equation 1 is necessary to make the relationship between a categorical outcome variable and its predictor(s) and Lemeshow, 2000) and result was interpreted by odds ratio. Data analysis was done by statistical software packages SAS 9.2 and RStudio.

\section{Results}

The average Body weight (Kg), Daily milk production (L), Lactation period (m), Age of first calving $(\mathrm{m})$ and Calving interval (m) of local and cross breed were 131.49 and $253.3 \mathrm{~kg}, 1.66$ and 6.63 liters, 7.41 and 10.8 months, 35.36 and 41.55 months, and, 14.96 and 15.2 months respectively presenting in Table 1.

linear. A binary logistic regression model was fitted with least significant value $<0.05$ (Hosmer

Table 1. Descriptive statistics of different quantitative variables

\begin{tabular}{llccc}
\hline Variables & \multicolumn{2}{c}{ Local } & \multicolumn{3}{c}{ Cross } \\
\cline { 2 - 5 } & Mean & St. Dev & Mean & St. Dev \\
\hline Body Weight (Kg) & 131.49 & 31.29 & 253.3 & 77.12 \\
Daily milk production (L) & 1.66 & 0.68 & 6.63 & 2.8 \\
Lactation period (m) & 7.41 & 2.25 & 10.8 & 3.17 \\
Age of first calving (m) & 35.36 & 5.4 & 41.55 & 6.18 \\
Calving interval (m) & 14.96 & 4.92 & 15.2 & 4.79 \\
\hline
\end{tabular}

The bar diagram shows in Fig. 1 represent the overall frequency percent distribution where 36 (34.3\%) and $34(32.4 \%)$ cows were in third and second parities respectively. The maximum frequency of milking daily once was found 87 (82.9\%), and 29 (27.6\%) owner collect milk by Gowala (Professional milkers) and remaining 76

(72.4\%) by himself but the proportion of vitamin used during lactation period was only 29 (27.6\%). It was observed that, 98 (93.3\%) owner used regular anthelmintic and anthrax and FMD vaccine were used in $20(19 \%)$ and $23(21.9 \%)$ cases respectively and the remaining 62 (59\%) reared their cows without any vaccination.
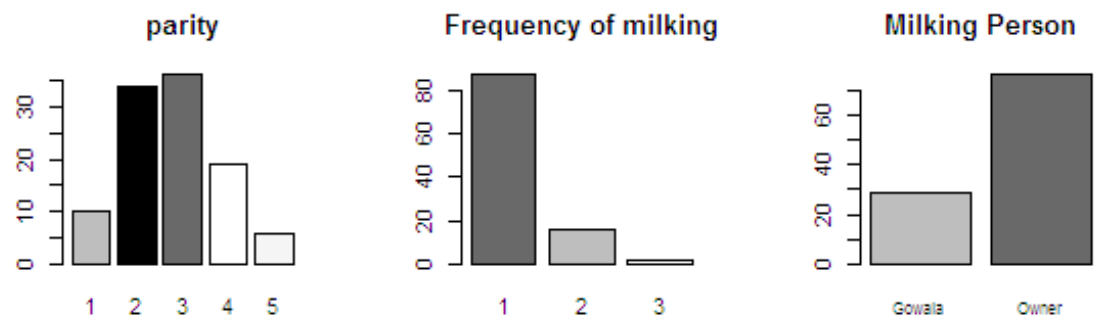

Vitamin use during lactatior

Anthelmentics use

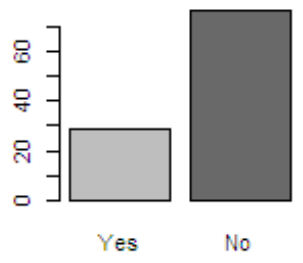

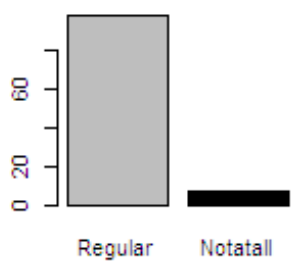

Fig. 1. Bar diagram of different categorical variables 
The pie chart presents in Fig. 2 portrays the calving in summer, rainy and winter were frequency and percentage distribution of different respectively 50 (48\%), 16 (15\%) and 39 (37\%). variables. Among the cows, local and cross breed The number of vaccinated cows were only 42 were $85(81 \%)$ and $20(19 \%)$ where only $8(8 \%)$ and $7(7 \%)$ cows showed the clinical sign of mastitis and FMD respectively. The season of makes up $41 \%$. In case of cowsheds, the brick floor and mud floor were found 69 (56\%) and 46 (44\%) respectively.
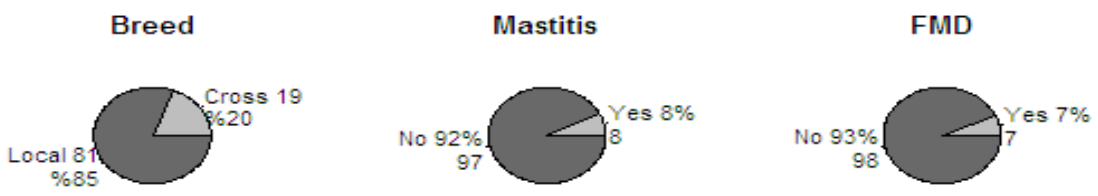

Season of Calving

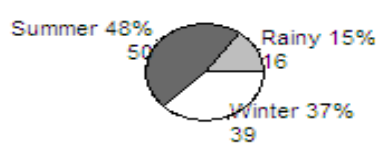

Type of Floor

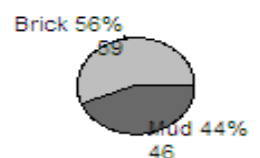

Fig. 2. Pie-chart of different categorical variables

A contingency analysis was conducted to observe the frequency and percentages among the different cells distribution. Table 2 depicts the frequency and percentage distribution among different categorical variables based on binary milk production categorized based on median (50\%). Body weight, age of first calving, lactation period, calving interval were categorized based on median and only significant covariates were considered. In category of $\leq 2 \mathrm{~L}$ average milk production, maximum frequency and percentages were (44) $83.02 \%$, (56) $73.68 \%$ and (59) $85.51 \%$ found within $\leq 140, \leq 36$ and $\leq 8$ of body weight $(\mathrm{kg})$, age of first calving $(\mathrm{m})$ and lactation period(m), which was (29) $55.07 \%$, (18) $62.77 \%$ and (28) $77.78 \%$ in $>140 \mathrm{~m},>36 \mathrm{~m}$ and $>8$ for category of $>2 \mathrm{~L}$ milk production respectively. The maximum proportion was found (57) $75 \%$, (37) $80.43 \%$ and (56) $73.68 \%$ for no vitamin use, mud floor and owner for the category of $\leq 2 \mathrm{~L}$ milk production, wherever, it was (19) $65.52 \%$, (29) $49.15 \%$ and (18) $62.07 \%$ for vitamin use, brick floor and gowala in the category of $>2 \mathrm{~L}$ milk production.

From the binary logistic regression analysis, it was observed some variables were significantly associated with milk production. The odds of milk production $>2$ liters for body weight $>140 \mathrm{~kg}$ was 6.16 times than that of body weight $\leq 140 \mathrm{~kg}, 4.58$ times higher for age of first calving of $>36 \mathrm{~m}$ than $\leq 36 \mathrm{~m}, 20.65$ times higher for lactation period $>8 \mathrm{~m}$ than $\leq 8 \mathrm{~m}$ and, 5.7 times higher for vitamin use than no vitamin used cows. The probability of milk production $>2$ liters for mud floor type was 0.25 times lower than that of brick floor type and 0.22 times lower in owner milking than gowala.

Table 2. Percent distribution of different categorical variables on the basis of milk production

\begin{tabular}{|c|c|c|c|c|c|c|}
\hline \multirow[t]{2}{*}{ Variables } & \multirow[t]{2}{*}{ Category } & \multicolumn{2}{|c|}{ Milk production (liters) } & \multirow[t]{2}{*}{ Total } & \multirow{2}{*}{$\begin{array}{c}\text { Odds } \\
\text { Ratio(OR) }\end{array}$} & \multirow[t]{2}{*}{$95 \%$ CI of OR } \\
\hline & & $\leq 2(\%)$ & $>2(\%)$ & & & \\
\hline \multirow{2}{*}{ Body Weight (Kg)* } & $\leq 140$ & $44(83.02)$ & $9(16.98)$ & 53 & \multirow[t]{2}{*}{6.16} & \multirow[t]{2}{*}{$2.50,15.19$} \\
\hline & $>140$ & $23(44.23)$ & $29(55.77)$ & 52 & & \\
\hline \multirow{2}{*}{ Age of first calving(m)* } & $\leq 36$ & $56(73.68)$ & $20(26.32)$ & 76 & \multirow[t]{2}{*}{4.58} & \multirow[t]{2}{*}{$1.85,11.35$} \\
\hline & $>36$ & $11(37.93)$ & $18(62.07)$ & 47 & & \\
\hline \multirow{2}{*}{ Lactation Period (m)* } & $\leq 8$ & $59(85.51)$ & $10(14.49)$ & 69 & \multirow[t]{2}{*}{20.65} & \multirow[t]{2}{*}{$7.35,58.00$} \\
\hline & $>8$ & $8(22.22)$ & $28(77.78)$ & 36 & & \\
\hline \multirow{2}{*}{ Vitamin Use* } & No & $57(75.00)$ & $19(25.00)$ & 76 & \multirow[t]{2}{*}{5.70} & \multirow[t]{2}{*}{$2.26,14.38$} \\
\hline & Yes & $10(34.48)$ & $19(65.52)$ & 29 & & \\
\hline \multirow{2}{*}{ Type of Floor* } & Brick & $30(50.85)$ & $29(49.15)$ & 59 & \multirow[t]{2}{*}{0.25} & \multirow[t]{2}{*}{$0.10,0.61$} \\
\hline & Mud & $37(80.43)$ & $9(19.57)$ & 46 & & \\
\hline \multirow{2}{*}{ Milking Person* } & Gowala & $11(37.93)$ & $18(62.07)$ & 29 & \multirow[t]{2}{*}{0.22} & \multirow[t]{2}{*}{$0.09,0.54$} \\
\hline & Owner & $56(73.68)$ & $20(26.32)$ & 76 & & \\
\hline
\end{tabular}

$*$ p-value $<0.01$ 


\section{Discussion}

From the study, it was revealed that, significant relation was pragmatic between milk production and age at first calving which was consistent with previous literature (Pirlo et al., 2000; Bayram et al., 2009; Bajwa et al., 2004). On the other hand, no significance relation of age of first calving with milk production in Brown Swiss Cattle investigated by Bayram et al. (2009). Lactation period was significantly associated with milk production, which was similarly demonstrated in the research result of Baul et al. (2012). In case of parity, no significant relation between milk yield and $4^{\text {th }}$ gives the highest production. Dhumal et al. (1989) found no relation between milk yield and parity. Similarly, $4^{\text {th }}$ parity was detected with highest production by Bajwa et al. (2004) whereas Tahir et al. (1989) registered $5^{\text {th }}$ lactation. Similar significant effect of vitamin use on milk production of this study was observed by Bregsten et al. (2003) for high yielding cows whereas $20 \mathrm{mg}$ of supplemental biotin per day in higher producing cows ( $>75$ lbs day $^{-1}$ ) increase milk production 2 to 7 lbs day-1 but no response in lower producing cows $\left(<45\right.$ lbs day $\left.{ }^{1}\right)$. In this study, floor type has significant effect on milk production, in opponent, no significant relation was observed by Kremer et al. (2007). In this study, there was no significant relation between anthelmentic use and milk production. However, a study by Gross et al. (1999) delineated that a median increase in milk production of 0.63 $\mathrm{kg} / \mathrm{cow}$ per day might be expected after anthelmintic treatment. Another study of meta analysis done by Sanchez et al. (2004) showed that on average, an increase of milk production of $0.35 \mathrm{~kg} \mathrm{cow}^{-1}$ day $^{-1}$ might be expected after anthelmintic treatment of naturally infected lactating dairy cows. Finally it was observed that the milk production was 0.22 times lower for owner milkers than gowala, this may be due to owner's inefficiency or their tendency to give the adequate milk left for calf.

\section{Acknowledgements}

The author thanks to Veterinary Surgeon of Gaibandha Upazila Livestock Hospital and all farmers who provided information during conducting this study.

\section{References}

Alam, M.G.S. and Ghosh, A. 1994. Plasma and milk progesterone concentrations early pregnancy in Zebu cows. Asian Australasian J. Animal Sci. 7: 131- 136.

Bajwa, I.R., Khan, M.S., Khan, M.A. and Gondal, K.Z. 2004. Environmental factors affecting milk yield and lactation length in Sahiwal cattle. Pakistan Vet. J . 24(1): 23-27.
Baul, S., Cziszter, L.T., Acatincăi, S., Gavojdian, D., Tripon, I., Erina, S. and Răducan, G.G. 2012. Phenotypic correlations among milk yield and chemical composition per normal lactation in Romanian black and white Breed. Animal Sci. Biotech. 45 (2): 275-277.

Bayram, B., Yanar, M. and Akbulut, O. 2009. The effect of average daily gain and age at first calving on reproductive and milk production traits of brown swiss and holstein friesian cattle. Bulgarian J. Agril. Sci. 15 (5): 453462.

BBS . 2008. Statistical Pocketbook of Bangladesh. Bangladesh Bureau of Statistics, Statistics Division, Ministry ofPlanning, Government of the People of Republic of Bangladesh, Dhaka. p. 256.

Bergsten, C., Greenough, P.R., Gay, J.M., Seymour, W.M. and Gay, C.C. 2003. Effects of biotin supplementation on performance and claw lesions on a commercial dairy farm. J. Dairy Sci. 86: 3953-3962.

Dhumal, M.V., Salhare, P.G. and Deshpande, K.S. 1989. Factors affecting lactation milk yield and lactation length in Red Kandhari and crossbred cows. Indian J. Dairy Sci. 42: 102104.

Djemali, M. and Freeman, A.E. 1987. Reporting of dystocia scores and effects of dystocia on production days open, and days dry from dairy herd improvement data. J. Dairy Sci. 70: 2127-2131.

Gross, S.J., Ryan, W.G. and Ploeger, H.W. 1999. Anthelmintic treatment of dairy cows and its effect on milk production. Vet. Rec. 144: 581- 587.

Hosmer, D.W. and Lemeshow, S. 2000. Applied Logistic Regression. New York: John Wiley and Sons, 2nd edition. pp. 147-156.

Jahan, M.K.I. Chowdhury, M.M.R., Nahar, S.M.Z.H. and Rahman, M.F. 1990. Performances of local and cross-bred dairy cows in farm condition. The Bangladesh Veterinarian, 7: 48-49.

Kremer, P.V., Nueske, S., Scholz, A.M..and Forester, M. 2007. Comparison of claw health and milk yield in dairy cows on elastic or concrete flooring. J. Dairy Sci. 90 (10): 4603-11.

Pirlo, G., Miglior, F. and Speroni, M. 2000. Effect of age at first calving on production traits and on difference between milk yield returns and rearing costs in Italian Holsteins. J. Dairy Sci. 83: 603- 608.

Rahman, M.S. Ahmed, M. and Ahmed, A.R. 1987. A comparative study on some productive and reproductive performance of dairy cows at Savar Dairy cattle improvement farm. Bangladesh Vet. J. 21: 55-61. 
Rehman, M.S., Nooruddin, M., and. Rahman, M.N. 1997. Prevalence and distribution of mastitis in crossbred and exotic dairy cows. The Bangladesh Veterinarian, 14: 104.

Sanchez, J., Dohoo, I., Carrier, J. and DesCoteaux, L. 2004. A meta-analysis of the milk-production response after anthelmintic treatment in naturally infected adult dairy cows. Preventive Vet. Med. 63: 237- 256.

Sarder, M.J.U. 2001. Reproductive and productive performances of indigenous cows. The Bangladesh Veterinarian, 18: 123-129.

Tahir, M., Qureshi, M.R. and Ahmad, W. 1989. Some of the environmental factors influencing milk yield in Sahiwal cows. Pakistan Vet. J. 9: 173-175.

Weiss, W.P. 1998. Requirements of fat-soluble vitamins for dairy cows: A review. J. Dairy Sci. 81: 2493- 2501

Wiltbank, J.B. 1970. Research needs in beef cattle reproduction. J . Animal Sci. 3: 755-762. 